\title{
A Clinical Didactics Analysis of the Use of Proxemics Forms in the Teaching-Learning Process of Sports and Physical Education Setting: A Case Study in Tunisia
}

\author{
Hejer BEN JOMÂA \\ Higher Institute of Sport and Physical Education of Tunis, Manouba University. \\ UMR EFTS, Jean-Jaures Toulouse University, \\ UR ECOTIDI (UR16ES10). Virtual University, Tunisia.
}

Hiba ABDELKAFI KAROUI

Higher Institute of Sport and Physical Education of Sfax, Sfax University. UR ECOTIDI (UR16ES10). Virtual University, Tunisia.

Hela CHIHI

UMR EFTS, Jean-Jaures Toulouse University, UR ECOTIDI (UR16ES10). Virtual University, Tunisia.

\section{Selma MAJDOUB}

UR ECOTIDI (UR16ES10). Virtual University, Tunisia.

Georges KPAZAї

School of Human kinetics, Laurentian University, Sudbury (ON), Canada.

\begin{abstract}
This paper aims to explore the link between teacher's use of proxemics and the "link to body" and its impact on teaching act through the analysis of the teaching practice of one Physical Education (PE) teacher named (E). Relying on a clinical didactic methodology based on a "case study" (Terrisse, 2003; Ben Jomaa, Chihi, Sghaier, Mami \& Kpazaï, 2017), two types of data were collected. The observation and the video recording of two PE sessions (gymnastics and volleyball) allows to obtain quantitative data in terms of the amount of proxemics types (Hall, 1966) used by the teacher in each teaching session. To collect the qualitative data, different types of interviews (already-there, post-stroke, ante and post session) were conducted with the same teacher in different research temporalities. As a result, the triangulation of these two types of data (Huberman \& Miles \& De Backer, 1991) shows an obvious correlation between the use of proxemics types and the link to body (Jourdan, 2006). When he gets close, especially in gymnastics setting, he maintains an intimate link to the body through touching and manipulating liberally student's body parts. When he stays distant, he
\end{abstract}


sometimes shows a narcissistic aspect by showing off his corporal skills in terms of his unconscious "impossible to support", although he sometimes manifests a distant and repulsive link to body when he faces a paucity of knowledge especially in volleyball.

Keywords: Didactic distance; Link to body; Clinical didactic; Proxemics; Physical Education Teacher.

\section{Introduction}

Teaching is primarily known as an interactive profession that requires permanent interaction between different "actors" of the teaching-learning process (Goffman, 1974). This interaction, mainly nonverbal, involves the human body as its major tool. A quiet number of researches have studied the proxemics form of the nonverbal didactic interaction (Forest, 2006; Vinson, 2013; Sghaier, Ben Jomâa, Mami \& Bouassida, 2016). Similarly, many others have focused on the use of the teacher's body in class and corporal language during teaching act (De Landsheere \& Delchambre, 1979; Pujade-Renaud, 1983; Ben Jomâa, Sghaier, Mami \& Kpazaï, 2017). However, a little amount of research has explicitly tackled proxemics from a corporal perspective despite of the crucial role of teacher's body in delivering knowledge and maintaining the didactic relationship in the teaching-learning process.

For this reason, the aim of this paper is to open up new reflections on PE teacher's corporal practice as a revealer of his own link to body and his internal phenomenon that mobilizes his actions in class. Therefore, we attempt in this paper to unveil this subjective relationship that teacher subject maintains with his own body through the study of nonverbal didactical interaction (proxemics) that he uses in in situ teaching act. Accordingly, the main objective of this current paper is to examine the impact that might have the "link to body" of one PE teacher on his teaching practice specifically on his use of proxemics. Indeed, our aim is to explore different types of "link to body" in accordance with the type of proximity deployed. In this context, two types of studies are required: a quantitative study by quantifying the use of different proxemics forms (Hall, 1966) by this teacher and a qualitative study using one "case study" (Terrisse \& Canus, 2009) to capture the singularity and the complexity of the subject.

In fact, the main purpose of the qualitative study is to examine the personal history of this didactic subject to identify the "impossible to support" (Terrisse, 2009; Touboul, 2011) through the study of his "already-there" (Carnus, 2002) and its impact on his "link to body" using the clinical didactic conceptual and methodological framework. In order to figure out the research problem, one male teacher was observed teaching two (2) PE sessions: one of gymnastics and one of volleyball for the same class.

In this study, two different types of sport activities (gymnastics and volleyball) were intentionally chosen in order to avoid any technical specification, especially in terms of requirement of proximity action, linked to an activity or another. For this reason, gymnastics was selected as an individual sport known as a morph-kinetic sport activity, which requires aid, body manipulation and 
protection as fundamental actions in learning-teaching process. Equally, we choose volleyball, a team sport which does not demand being too close to students for aid or manipulation. These two sport activities are clearly different in terms of the use of proximity types by the teacher in teaching act. Thus the assembly of them brings more legitimacy and credibility to our results concerning teaching act in spite of sport activity types observed.

\section{Problem and research questions}

In PE, the teacher's body is widely involved during the teaching-learning process due to the corporal and praxeological anchoring of knowledge. This leads us, obviously, to study the teacher's body as involved in teaching act and the link that he may establish with his own body. Moreover, while teaching, the teacher changes consciously or unconsciously the distance vis-à-vis his students. This interpersonal or inter-corporal distance that separates teacher's and student's bodies plays a crucial role in the regulation of didactical situations especially in PE setting, as the teacher's body is seen as the principal tool of teaching act and the main holder of "didactical know-how" (Jourdan, 2006) and the place where experience, emotion and cultural norms are embedded (Andrieu, 2010) through a long personal history.

On these bases, this article attempts to bring in clear answers to the following questions:

1) Does the personal history of PE teachers especially the "impossible to support" have an impact on the link that they establish with their own body?

2) Is there any relationship between the teacher's "link to body" and his professional use of different forms of proxemics?

\section{Conceptual framework}

The principal concept of the current paper is the "link to body". It refers to the emotive and intimate relationship that a person may establish with his own body. The body that we study here is not considered only as an amount of human flesh and organs, but more as these inseparable components of body "nailed" to soul or spirit according to Plato in Phaedo (Plato, 1956). This body has become an actual increasing concern in the current of research since 1970 (Andrieu, 2007), regarding its important role in human relationships especially in teacher-student relationship in school in general and in PE setting in particular. Indeed, teacher's body sends signs and messages unwittingly even it does not express verbally due to its "mediator role in teacher-student relationship" (Pujade-Renaud, 1983). It is a body that can express nonverbal massages through gesture, facial mimics, touches and distance, etc.

We are interested in "distance" or "proximity" as one of the nonverbal interaction forms and as an original didactic analyzer of teachers' action in class. This concept is defined according to the cultural anthropologist Edward Hall (1966: p.1) as the "the interrelated observations and theories of humans use of space as a specialized elaboration of culture". Originally, proximity served as a model to make intercultural comparisons between different nations in order to clarify the crucial role of inter-corporal distance as a way to express and regulate 
social interactions. For this purpose, Hall proposes four types of distance: public, social, personal and intimate (see table 1).

Sensevy, Forest and Barbu (2001) have inspired from the epistemological framework of social distance to create the concept of "didactic distance" in order to adapt it into education and didactics area. Indeed, the "didactic distance" is not considered only as the Euclidean or metric distance. It includes also body and sight direction as well as perception. As defined in his exploratory mathematical study, Forest (2001) created four new configurations of proxemics, inspired from Hall's distances models (1966-1973), which are presented as follows: public, social, remote personal, close personal. These new distance configurations, however, misses the intimate form. This was explained by the author that these new configurations seem to be more appropriate for the class context. Although, PE has a very interesting particularity, which is, on one hand, the unlimited class area unlike other subjects such as mathematics and geography. On the other hand, it requires in some cases that teachers get intimately close to students in order to adjust and fix their body movements even manually. Thereby, Hall's original distance configuration model was opted in data collection and analysis.

We also refer to the concept of "impossible to support" (Terrisse, 2009), inspired from Freudian and Lacanian psychoanalytical universe. This notion serves as a clinical didactic analysis tool of the regular teaching practice through the interpretation of their actions (didactic gesture and proximity) and their speech (Verbatim from sessions and interviews). For teachers, it refers to the impossible to say, to manage, to do, or to teach in general. In some cases, it refers also to the teacher's personal experience regarding an ancient trauma experienced as a sport practiced (Loizon, Margnes \& Terrisse, 2008).

\section{Method}

\section{Research participant}

An experienced male teacher named (E) had voluntary accepted to cooperate in our study. He is a gymnastics expert and has taught in secondary school for over 15 years. After setting all the administrative and ethical procedures, he accepted to teach two PE sessions including one session of gymnastics and one session of volleyball for the same third degree class over all of the observation.

\section{Data collection}

For the data collection, several technics were used in order to capture all sides of the didactic subject which was organized over three didactic times: before the teaching session, during the teaching session and after the teaching session.

The teaching sessions chosen to be studied took place the 19th and the $21^{\text {st }}$ of April 2016 in the same high school and in the same conditions. One week before filming, we have interviewed "a priori" teacher (E) for one hour in order to extract relevant information about his conceptual and experiential "alreadythere" (Carnus, 2015) and the way he may see his own body in teaching action. Indeed, an interview "ante session" of ten minutes took place before each session to reveal its theoretical continent and the teacher's expectations about it. 
During teaching session, it corresponds to the time of the "test" which refers to the time of reality of class and transmission of knowledge (Terrisse, 2000). At this time of data collection, an in situ video observation and filming of the entire two sessions were made using two cameras. The first one is stationary in order to take a wide shot of the area, while the other is mobile following teacher's movements around. All teacher's Verbatim was recorded using a lavalier microphone which was entirely and faithfully transcribed. Hence, two types of data had to be collected: quantitative data and qualitative data. Then, we relied on Hall's distance configurations to quantify the use of distance types by each teacher during both teaching sessions.

Just after each teaching session, an interview "post-session" of ten minutes long, was conducted with the participant in order to capture teachers' immediate first impressions related to the session.

Tree interviews "post-stroke" took place one month after the last filming and separated with almost one month. For the teacher, it corresponds to the time of redesigning of his position as a teacher. For the researcher, this time provides clear answers of some significant actions in order to figure out the link to body throw teachers' proxemics. All verbatim of interviews made, were totally recorded and faithfully transcribed to serve later in qualitative analysis.

Different types of data were collected from different times of research in intention to pin down all key elements of teachers' "link to body" and its impact on their teaching action.

\section{Data analysis}

Our research is both qualitative and quantitative. It is registered under a clinical didactic framework based on its original methods and tools. Throughout this study, the "case study" is used as a qualitative method in order to make "indepth" and "detailed" case analysis (Van Der Maren, 1995). This method seeks to encompass the teacher in his singularity and his complexity from the analysis of the didactical choices that he makes and the exploration of the intelligibility of his observed actions. Indeed, we share the perspective of Passeron and Revel (2005) who opt for the "rehabilitation" of the case study. These two researchers outlined the interest and the requirement of this type of study which "does not proceed without raising the question": "sciences of the case have ensured the convergence between descriptive value of clinical method and the methodological value of contextualized observation for the production of evidence" (Ibid). Furthermore, the EdiC (research team of clinical didactics) requires the "cumulativeness of results" as the contribution of its studies, which allows to produce theoretical analyzers, methodological tools and results which contribute to the comprehension of teaching practice in PE (Carnus \& Terrisse, 2013; Carnus, 2015). In fact, the comparative approach of the produced results allows tackling elements that structure teaching logic and show the difference between teaching practices of the didactic subject.

In intention to examine the particularity of the didactic subject, the data analysis was monitored the same times as the data collection. As two types of data were collected, the two types of analysis are inescapable: quantitative analysis and 
qualitative analysis. To analyze the different types of proxemics used by teacher (E), we relied on Hall's interpersonal distance scale model (1966) (See table 1) through videos analysis of both teaching sessions, which allows us also to spot all subjective determinant of unconscious teaching actions.

Table 1: Interpersonal distance scale (Hall, 1966-1973).

\begin{tabular}{|c|c|c|}
\hline Distance & Close mode & Remote mode \\
\hline $\begin{array}{c}\text { Intimate } \\
\text { (ID) }\end{array}$ & Corpse to corpse & From $15 \mathrm{~cm}$ to $40 \mathrm{~cm}$ \\
\hline $\begin{array}{c}\text { Personal conversation } \\
\text { (PCD) }\end{array}$ & From 45 to $74 \mathrm{~cm}$ & From 75 to $125 \mathrm{~cm}$ \\
\hline $\begin{array}{c}\text { Social interaction } \\
\text { (SID) }\end{array}$ & From $1,25 \mathrm{~m}$ to $2,10 \mathrm{~m}$ & From 2,10 to $3,60 \mathrm{~m}$ \\
\hline $\begin{array}{c}\text { Public } \\
\text { (PD) }\end{array}$ & From 3,60 $\mathrm{m}$ à $7,50 \mathrm{~m}$ & From $7,50 \mathrm{~m}$ beyond \\
\hline
\end{tabular}

Data triangulation process (Huberman \& Miles \& De Backer, 1991) and content analysis (Van Der Maren, 1995; Bardin, 1998) were employed in order to link and to give meaning to the "doing" and the "saying" of each teacher when in teaching.

\section{Results:}

Data collected from interviews conducted with the teacher and the observation made of two PE sessions allow to obtain two types of results: quantitative results and qualitative ones. Quantitative results illustrated in the first sub-section, show the percentages of the teacher's use of proxemics types in both sessions (gymnastics and volleyball). As for qualitative results, they are presented in both second and third sub-sections in terms of the "impossible to support" and the "link to body" of teacher (E).

\section{Proxemics}

The produced quantitative results from this study correspond to the percentages of each teacher's use of didactic distance types in both lessons. Statistical analyses were made with the statistical software "Sphinx Lexica V5".

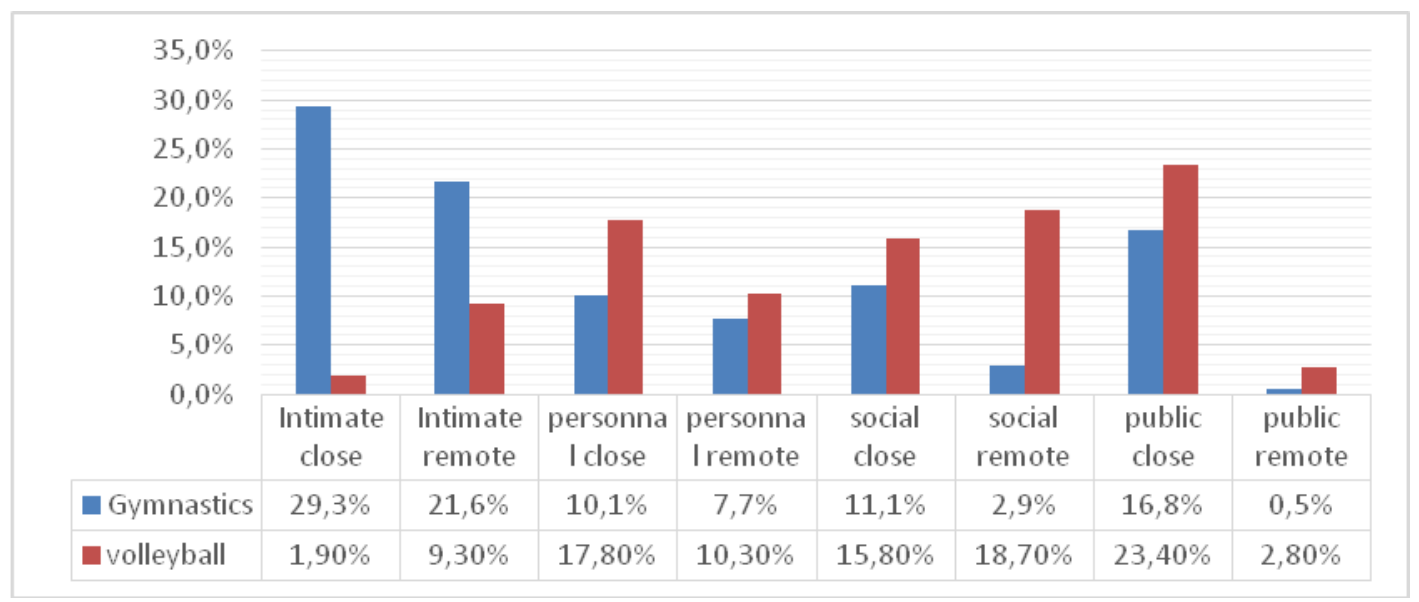

Figure 1: Types of didactic distances used by teacher $(E)$ in both sessions 
From Figure (1), a notable massive use of intimate and public distances is characterizing teacher's E gymnastics teaching. However, his volleyball teaching is preferably distant using social and public distances. In gymnastics teaching, teacher (E) uses intimate distance (close and remote) to correct and adjust fine segment movements of his student. In fact, he allows himself to touch and manipulate student's body parts in order to regulate and make them feel the right movement. For him, this close distance, especially in gymnastics teaching session, allows him to transmit the appropriate knowledge in a better way. He explains: "I don't mind touching and getting too close to any of my students, because this allows me to show and correct delicate movements more efficiently and accurately".

Furthermore, he deploys close public distance while demonstrating the movement by himself in both sessions. In fact, he seeks for all students' attention by displaying his body skills as he claims in one previous interviews: "sometimes, I ask my student to step back to see me ... I do the demonstration by myself and I maintain the balance for over fifteen seconds!". This distance allows him to take a step backward as to his students as well as the knowledge that he attempts to transmit (Ben Jomaa \& Terrisse, 2014). As a result, it is quiet obvious that teacher (E) changes the didactic distance sometimes consciously and sometimes unconsciously for didactical purposes to regulate, to demonstrate and to illustrate knowledge via his body. In fact, subjective determinants seem to monitor his behavior in class and have an obvious impact on his decision making process (Carnus, 2003).

\section{The impossible to support}

Through interviews and videos analyses, it is notable that, for teacher (E), the fact of "not demonstrating" is considered as an "impossible to support". Thus, he cannot handle teaching without showing off his body skills in both sports even if he is not a volleyball expert. He affirms: "I cannot imagine teaching gymnastics without demonstrating...", "...if we have skills and talent, why we hide them?". In this case, he uses distance to express this need of showing off, as he variates the interpersonal distance separating him from the targeted student(s).

\section{Link to body}

After studying the case of teacher (E), it is remarkable that his body is widely involved in teaching act during both sessions as he deploys with it an instrumental link. In fact, this "body" is considered for him as an inescapable teaching tool engaged in delivering knowledge that "must be always in a good shape and ready to respond to all teacher's needs in the right place and the right time". Indeed, he attempts to "impose his didactic authority" as a teacher via his body as he "claims a narcissistic pleasure of showing to others what he knows" (Buznic-Bourgeacq, 2009). Thus, the desire of "being noticed" strengthens in him the image of the body as an icon of perfection and ideal that needs to be seen and admired: "it is the paradox of the body at the same time image, object and significant" (Delanoé \& Labridy, 1983). Although, he manifests a distant, even a repulsive link to body when he is not able to provide the appropriate information. It is the lack of knowledge, especially in volleyball teaching, that 
causes this distance in regard to his student, to the body and to knowledge. As he cannot transmit knowledge that is eviscerated, gutted of his body. As a result, teacher (E) makes use of proximity as a didactic tool in daily teaching act and as reflection of his subjective resources in terms of link to body, link to knowledge and link to contingency (Jourdan \& Brossais, 2010; Ben Jomâa \& Terrisse, 2014).

This corporal inscription in his teaching act generates a singular and an intimate link with his body which refers to "a living body, professionally devoted in teaching-apprenticeship act, simultaneously a mediator and a tool, an action's author and a holder of meaning" (Jourdan, 2006). Furthermore, his corporal expertise and body-control as a gymnastics expert endows him the fluency of exposing his knowledge and assuming the responsibility of being a "subject supposed to know" (Lacan, 1977) that he attempts to preserve.

\section{Discussion}

This paper aims to discuss the "link to body" (Jourdan, 2006) of a PE teacher and its impact on his use of didactic distance (Forest, 2006) or "proximity" (Hall, 1973). Results arising from two types of analysis within a clinical didactic framework show a notable congruence between the "saying" and the "doing" of our study case during this research. In that respect, we argue that the link to body as a personal subjective determinant of the singularity of the didactic subject has an obvious impact on teaching act, including the use of proximity. For teacher (E), his body has a concrete and a unique nature through teaching gestures that he employs (McNeill, 2008) including proxemics which set him apart from others. It is about his singular way to make use of his own body to transmit knowledge and several corporal techniques (Sève \& Gal Petifaux, 2015). Indeed, the variation of the use of distance for a didactical purpose reveals a particular professional expertise (Tochon, 1993) of the teacher in terms of didactic ingenuity (Schubauer-Léoni \& Dolz, 2004), adaptation and reflection (Schön, 1984, 1987). In addition, the previous experience and practicum experience as a professional determines clearly the degree of development of professional knowledge (Singh, 2016) and the efficiency of transmitting knowledge. In fact, the corporal experience of teacher $(\mathrm{E})$ in terms of his long confrontation with a particular discipline, seems to have a notable impact on teaching act and professional practice (Ben Jomâa, Sghaier \& Mami, 2016). Indeed, this teacher seems to have a good control over different technics related to gymnastics as well as volleyball, which is so obvious due to massive use of demonstrations. As noticed, there was a remarkable dependence between the proximity used and types of ostension (exhibition of knowledge) implemented in teaching process, which will make the subject of future research.

\section{Conclusion}

To conclude, clinical didactic analysis of our case study put in evidence the impact of the "link to body" of PE teachers, as an unescapable notion in PE researches, on their teaching act in class especially on proximity. The triangulation of quantitative and qualitative results shows a remarkable congruence between the use of didactic distance types and the relationship that PE teachers may establish with their own bodies. In fact, PE teacher obviously 
variates the distance in regard to his student(s) according to his link to knowledge, and to body which is sometimes intimate and close, sometimes repulsive and distant (Ben Jomâa \& Terrisse, 2014). Furthermore, subjective determinants throw personal and professional experience in terms of the impossible to support and the link to knowledge; seem to contribute to the built of the personal conceptions of the teacher as well as his link to body. This shows that the variation of use of distance types in teaching act refers also to the teacher's link to knowledge as a final statement shows that the link to body is eventually a link to incorporated knowledge. In fact, PE teacher establishes, consciously or unconsciously, a personal relationship to knowledge integrated in his personal corporal experience through years of practice, training and teaching. It is about a personal and corporal investment in teaching act due to his sport expertise as a highly erudite sports man.

Finally, we hold up to emphasize that we do not intend to generalize our results, as it is about a singular case study that does not resemble any other cases. Although, we are clearly aware of these limitations, we share the statement that: "the most singular of a personal experience may testify from the universal of all human condition" (Terrisse, 2000). the aim of the present study is to heighten the awareness of teachers and instructors as to the importance of proxemics and the "link to body" in teaching-learning process in order to implement these notions in the preservice and continuous education programs for students and teachers in all disciplines in general and particularly in PE setting.

\section{References}

Andrieu, B. (2007). Les rayons du monde : l'espace corporel avec Merleau Ponty (Rays of the world: the corporal space with Merleau Ponty). Série. Documents de travail, MSH EHESS Paris, 175-183.

Andrieu, B. (2010). Philosophie du corps (The philosophy of the body). Paris : Vrin.

Bardin, L. (1996). L'analyse de contenu (The content analysis). Paris : PUF.

Ben Jomaa, H., Chihi, H., Sghaier, D., Mami, M., \& Kpazaï, G. (2017). The Impact of Professional Experience on Teaching Conceptions in University. Case Studies from Tunisia. European Journal of Educational Sciences (ejes), vol. 4, N³, 74-88. http://dx.doi.org/10.19044/ejes.v4no3a7

Ben Jomaa, H., Sghaier, D., Mami, M., \& Kpazaï, G. (2017). The effect of the relationship to the knowledge of physical education teachers on ostensive forms in swimming. European Journal of Educational Sciences (ejes). Vol. 4, N4, 11-23. http://dx.doi.org/10.19044/ejes.v4no4a2.

Ben Jomaa, H., Sghaier, D., \& Mami, M. (2016). The Impact of Personal Experience on the Professorial Practice in Physical Education: A Case Study from Tunisia. Creative Education, 7, 1328-1334. https://doi.org/10.4236/ce.2016.79137

Ben Jomâa, H., \& Terrisse, A. (2014). L'effet d'un " déjà-là " sur la pratique d'un enseignant : le point de vue de la didactique clinique de l'EPS (The effect of an "already-there » on teacher's practice: the point of view of PE clinical didactic). Recherches en Education, 20, 116-128

Buznic-Bourgeacq, P. (2009). La transmission du savoir expérientiel. Études de cas et analyses comparatives en didactique clinique de l'EPS (The transmission of experiential knowledge. Cases studies and comparative analysis in PE clinical didactic). Thèse de doctorat. Université Paul Sabatier. Toulouse 3. 
Carnus, M.-F. (2015). Le rapport au(x) savoir(s) du sujet-enseignant en didactique clinique de l'EPS : un " déjà-là décisionnel » (The relationship to knowledge of the teacher in clinical didactics of the Physical Education: One already there decision-making). In V. Vincent \& MF, Carnus (dir.). Le rapport au(x) savoir(s) au cœur de l'enseignement. Enjeu, richesse et pluralité., pp. 61-73. De Boeck. Bruxelles.

Carnus, M.F. (2003). Analyse didactique du processus décisionnel de l'enseignant d'EPS en gymnastique: une étude de cas croisés (Didactical analysis of decisional process in gymnastics of PE teacher : a corossed case studies). In :C Amade-Escot (éd) Didactique de l'éducation physique, état des recherches, 195-224, Paris : Revue EPS.

Carnus M.-F., Terrisse A. (2013). Didactique clinique de l'EPS. Le sujet enseignant en question (PE clinical didactic : the teaching subject in question). Paris : Éditions EPS.

De Landsheere, G., Delchambre, A. (1979). Les comportements non-verbaux de l'enseignant (The teacher's non-verbal behavior). Bruxelles : Labor.

Delanoé, M.-H., Labridy, F. (1983). Formation des enseignants d'EPS et psychanalyse (Course of PE teachers and psychoanalysis). Revue EPS, $\mathrm{n}^{\circ}$ 184, pp. 31-34.

Forest, D. (2001). Distance élèves-maître en activité didactique (Teacher-student distance in didactic activity). Mémoire de DEA en sciences de l'éducation, université de Nantes.

Forest, D. (2006). Analyse proxémique d'interactions didactiques (Proxemics analysis of didactic interaction). Carrefours de l'éducation, (1), 73-94. https://doi.org/10.4000/books.septentrion. 14900

Goffman, E. (1963). Behavior in public places: notes on the social order of gatherings. https://doi.org/10.2307/2091496

Hall, E. T. (1966). The hidden dimension.

Hall, E. T. (1973). The hidden dimension. Leonardo, 6(1), 94. https://doi.org/10.2307/1572461

Huberman, A. M., Miles, M. B., \& De Backer, C. (1991). Analyse des données qualitatives : recueil de nouvelles méthodes (The analysis of qualitative data: collecting new methods), 88-138. Bruxelles : De Boeck Université.

Jourdan, I. (2006). Rapport au corps, rapport aux activités physiques, sportives et artistiques et logique professionnelle : deux études de cas en formation initiale en EPS (Link to body, Link to physical, artistic and sports activities and professional logic : two cases study in pre-service education in PE. Aster, 42, 5778. https://doi.org/10.4267/2042/16792

Jourdan, I., \& Brossais, E. (2010). Du rapport au savoir au rapport à l'épreuve (From the link to knowledge to the link to test). Recherche $\mathcal{E}$ formation, (3), 9-22. https://doi.org/10.4000/rechercheformation.1064

Lacan, J. (1977). Ouverture de la section clinique (Openinig of the clinical section). Ornicar, 9,7-14.

Loizon, D., Margnes, É., \& Terrisse, A. (2008). Analyse des pratiques d'enseignement du judo en EPS (Analysis of teaching practice of judo in PE). eJRIEPS, 14, 63-82.

McNeill, D. (2008). Gesture and thought. University of Chicago press. https://doi.org/10.1017/cbo9780511620850.009

Passeron J.C. \& Revel J. (2005). Penser par cas (Thinking by case). « Enquête ». Paris. École des Hautes Études en Sciences sociales.

Plato, R. (1952). Plato's Phaedo. https://doi.org/10.1017/cbo9780511620287

Pujade-Renaud, C. (1983). Le corps de l'enseignant dans la classe (Teacher's body in class). Paris : ESF.

Schön, D. A. (1984). The reflective practitioner: How professionals think in action (Vol. 5126). Basic books. https://doi.org/10.4324/9781315237473 
Schön, D. (1987). Educating the reflective practitioner. Journal of continuing Education in the health Professions, 9, 2, 115-116.

Schubauer-Leoni, M.-L. \& Dolz, J. (2004). Comprendre l'action et l'ingéniosité didactique de l'enseignant : une composante essentielle de la transformation de l'École (Underestanding action and teacher's didactic ingeniosity: an essential component of school transformation) . In J.-P. Bronckart \& M. Thurler Gather (Éd.), Transformer l'école (pp. 147-168). Bruxelles : De Boeck (coll. Raisons Éducatives). https://doi.org/10.3917/dbu.bronc.2004.01.0147

Sensevy, G., Forest, D., \& Barbu, S. (2005). Analyse proxémique d'une leçon de mathématiques: une étude exploratoire (Proxemics analysis of a mathematical session: an exploratory study). Revue des sciences de l'éducation, 31 (3), 659-686. https:// doi.org/10.7202/013914ar

Sève, C., \& Gal-Petitfaux, N. (2015). Les techniques corporelles en éducation physique (Corporal techniques in PE).

Sghaier, D., Jomaa, H. B., Mami, M., \& Bouassida, A. (2016). The Combination of the Physical Ostension to the Verbal Ostension in Swimming Revealing of Professioral Action. Creative Education, 7(03), 500-505. https://doi.org/10.4236/ce.2016.73051

Singh, A. (2016). Impact on Teaching: Consistent Knowledge Development, Reflection and Practice. International Journal of Learning, Teaching and Educational Research, 15(10).

Terrisse, A. (2000). Epistémologie de la recherche clinique en sports de combat (Clinical research epistemology in combat sport). Recherches en sports de combat et en arts martiaux, 95-108.

Terrisse, A. (2003). Prise en compte du sujet et recherche en didactique des sports de combat: bilan et perspectives (The inclusion of the subject and research in combat sport didactic). Science et motricité, 50, 55-79. https://doi.org/10.3917/sm.050.0055

Terrisse, A. (2009). Chapitre 1. La didactique clinique en EPS. Origine, cadre théorique et recherches empiriques (PE clinical didactic. Origin, theoretical framework and empirical research). In Didactique clinique de l'éducation physique et sportive (EPS) (pp. 13-31). De Boeck Supérieur.

Terrisse, A \& Carnus, M.F (2009). Didactique clinique de l'EPS : quels enjeux de savoirs ? ( PE clinical didactic: what are the issues of knowlege)Bruxelles: De Boeck Université.

Touboul, A. (2011). Les effets de l'expérience et de l'expertise dans les pratiques enseignantes en EPS : étude didactique clinique en Savate Boxe Française (The effects of experience and expertise in PE teaching practices: clinical didactic study in French boxing). Thèse de doctorat, Université Toulouse le Mirail-Toulouse II.

Tochon, F. V. (1993). Le fonctionnement « improvisationnel » de l'enseignant expert (The "improvisational » functionning of the expert teacher). Revue des sciences de l'éducation, 19(3),437-461. https://doi.org/10.7202/031641ar

Van Der Maren J.M. (1995), Méthodes de recherche en éducation (Research methods in education), Bruxelles, De Boeck Université.

Vinson, M. (2013). Sous la dynamique non verbale des interactions didactiques, le genre Analyse de l'action conjointe du professeur et des élèves: deux études de cas en EPS (Under the dynamism of the non verbal didactical interactions, the gender. Analysis of conjoint action of the teacher and students: two cases study in PE). Thèse de doctorat en Sciences de l'Éducation non publiée, Université de Toulouse 2 - Le Mirail. 